\title{
The Effectiveness of the Service of the Police Record Certificate Under the Standard Operating Procedure
}

\author{
Andriansyah Kartadinata ${ }^{1}$, Muhammad Arief Koenang ${ }^{2}$, Indah Kusuma Wardhani ${ }^{3}$ \\ \{andri86policelightstore@gmail.com¹, Ariefkoenang@gmail.com², \\ indah_kusuma_wardhani@yahoo.com ${ }^{3}$ \} \\ Universitas Borobudur, Jakarta, Indonesia ${ }^{1,2,3}$
}

\begin{abstract}
The police record certificate service is part of the public service provided by the Indonesian National Police to the public. This SKCK is used for specific requirements so that it needs fast and good service. The method used in this paper is descriptive qualitative with descriptive analysis. The results obtained from this paper are that the services provided by the police are pretty good, but now, with a touch of information technology, it is even faster. This study concludes that the police face many obstacles.
\end{abstract}

Keywords: Effectiveness; Police Record Certificate; Standard Operating Procedure

\section{Introduction}

Public service is a problem that needs comprehensive attention and resolution. Such a hypothesis, qualitatively, for example, can be easily proven where we see a lot of demands for public services as a sign of dissatisfaction daily. Every person requires assistance. Even in the most severe cases, service cannot be divorced from human existence. The role of public services organized by the government involving all civil servants is increasingly felt by the increasing awareness of the state and society. The service has increased its position in the community's eyes into a right, namely the right to service. Therefore, in public services, it is still under improvement in various sectors [1].

The improvement to improve excellent and excellent service. People now demand good service, which has become the right of the community to get good service, and it has become an obligation for civil servants to provide full service [2]. Service is a way of providing services, responding to, managing, and resolving the needs of a person or group of people. Service activities usually involve the fulfillment of a right, such as those carried out by government agencies at the center, in the regions, and within State-Owned Enterprises (BUMN), Regional-Owned Enterprises in the form of products and services, both in the framework of efforts to address community needs and in the context of implementing provisions Legislation. Public service is defined as the providing of services (serving) to other individuals or the community who have an interest in the organization while adhering to the organization's basic rules and procedures.

Public service is the activity of delivering services and meeting the requirements of members of the community who have an interest, carried out by service providers under the 
goals, regulations, and procedures established by commercial or government organizations earlier [3]. Public services have various factors that influence them. Public services are closely related to service quality because public services are related to the community so that every service must have a high value [4]. As law enforcers and security and public order supervisors, the Police of the Unitary State of the Republic of Indonesia The principal duty of the National Police, as defined in Article 2 of Law Number 2 of 2002 concerning the National Police, is to serve as a law enforcer, protector, and guide of the community, particularly in the context of compliance and adherence to relevant laws [5].

The police have an essential role in providing services to the community related to security and other community needs [6]. So in implementing police services, it is necessary to increase the performance of services, especially services from police officers to the community. So that the condition of the community environment can be conducive, the police need to improve the quality of service by utilizing the technology that is currently developing. One form of public service provided by the government through the police is making a police record certificate (SKCK). Kapolri Regulation Number 18 of 2014 about Procedures for Issuing Police Records Certificates governs the issue of SKCK. The authority to issue SKCK is carried out at the Polsek, Polres, Polda, and Headquarters levels.

The making of SKCK can also be done at the police station, police station, or local police according to their individual needs and the address or domicile of the SKCK applicant. Regarding the manufacture of SKCK, there must be ups and downs in demand every year for making SKCK. The demand for SKCK will increase or decrease depending on the needs of the community or the applicant. This study is intended to see and explain what strategies are implemented by the Salatiga Police to improve the quality of services provided to applicants or the community. In addition, this study also aims to explain whether existing strategies are possible or not to support improving the quality of service for making SKCK at the Salatiga Police Station.

\section{Methodology}

The approach in this research uses the descriptive-analytical method. The type of research method chosen is descriptive analysis. The descriptive-analytical approach, on the other hand, is a method that uses data or samples gathered as-is to describe or present an overview of the topic under investigation without analyzing or drawing conclusions that are applicable to the general public. In other words, when conducting research, analytical descriptive research considers difficulties or focuses emphasis on topics. The study's findings are subsequently processed and examined to get a conclusion. The author employs the descriptive analysis approach since it is appropriate for understanding the present phenomena.

This research is field research that describes or explains and provides as detailed data as possible regarding the effectiveness of the Police Records Certificate (SKCK) service at the Salatiga Police Station. The data obtained from the research results will be analyzed using a descriptive analysis method that explains clearly with sentences to answer the question of SKCK services at the Salatiga Police Station. 


\section{Results and Discussion}

\subsection{Service effectiveness of Police Records Certificate following Standard Operating Procedures}

Components of service standards based on Article 21 of Law no. 25 of 2009 concerning public services are as follows: 1) Legal Basis 2) Requirements 3) Mechanisms and Procedures System 4) Completion Period 5) Fees/Tariffs 6) Service Products 7) Facilities or Facilities 8) Implementing Competencies 9) Internal Monitoring 10) Handling, Complaints and Feedback 11) Service guarantees that provide certainty are carried out per service standards 12) Evaluation of implementation performance.

The following are factors that affect the implementation of standard operating procedures in making a certificate of loss. According to the ideal role, The National Police, as an instrument of the state that preserves security and public order, has the mission of protecting, according to Article 30 paragraph (4) of the 1945 Constitution. nurturing, serving the community, and enforcing the law. The supposed role of Article 13 letter c is 103 "The main task of the police is to provide protection, protection, and service to the community." The actual role is that law enforcers should be able to "mulat sarira" or "introspective", which will appear in the behavior that implements their fundamental part. To be able to be introspective, law enforcement must try to live. In carrying out their duties, members of the Indonesian National Police are prohibited from making illegal levies in any form for personal, group, or other party interests.

Work is an obligation that all police officers must carry out without exception according to their respective responsibilities. Carry out a trustworthy task by prioritizing honesty with oneself. Prioritizing the right of the community to get services as they should. The initial sentence seen when entering the police service agency is "WE ARE READY TO SERVE YOU" this proves that the police attach great importance to and prioritize services, especially the community. The apparatus is obliged to serve, and the community has the right to receive good service. The concept of value becomes very important because values and norms guide the choice of action and the moral basis for justifying and evaluating ethical behavior. Creating value through analysis, understanding, and application is an entry point for improving public services. Thus, applying responsibility becomes a form of public empowerment, especially for those who directly deal with the community [7].

The existence of rules and supervision can increase a sense of responsibility and encourage work result orientation. Increasing a sense of responsibility is expected to make public services more considerate and pay attention to the development of public service practices, the importance of addition and experience, continuous changes in working conditions and organization. Professional public service requires technical competence, which makes it effective and efficient, leading to value. The value system is seen in the professional ethics of the police, namely the reference for police officers to act, knowing actions that are motivated by norms as the beginning of taking wise steps and decisions without exception. Regulation of the Head of the National Police of the Republic of Indonesia number 14 of 2001 concerning the Code of Professional Ethics for the Police explains that the professional ethics of the Indonesian National Police is the crystallization of tribrata and chess values which are based on and inspired by Pancasila and reflect the identity of each member of the National Police in the form of moral commitment which includes state ethics, institutions, and personalities. 
a. The moral attitude of members of the National Police towards the Unitary State of the Republic of Indonesia, Pancasila, the Republic of Indonesia's 1945 Constitution, and the diversity of diversity is known as state ethics.

b. Institutional ethics is the moral attitude of members of the National Police towards institutions that serve as a place of devotion and deserves to be upheld as the inner and outer bond of all shadowy people with their dignity and honor per the values contained in Tribrata and Catur Prasetya

c. Personality ethics is the behavior of a member of the National Police in religious life, obedience, obedience, and courtesy in family life, society, nation, and state.

The meaning of the values of tri brata and chess prasetya in the form of a promise by the police as part of a person who is obedient to God Almighty and devotion to the homeland and nation is as follows: TRI BATA WE ARE THE INDONESIAN POLICE (1) Be devoted to the homeland and nation with complete devotion to God Almighty; (2) Upholding truth, justice, and humanity in keeping the laws of the unitary state of the Republic of Indonesia based on Pancasila and the 1945 Constitution; (3) Always protect, protect and serve the community with sincerity to create security and order. The principles of the police code of ethics (article 3) explain that in carrying out their duties to serve the community, including:

a. Propriety, namely standards or moral values that can be manifested in attitudes, words, and actions;

b. Legal certainty, clear guidelines for members of the National Police in carrying out their duties, authorities, and responsibilities in implementing the code of ethics;

c. Simple, namely the implementation of the code of ethics is carried out in an easy, fast, and accountable way while still upholding truth and justice;

d. Equality of rights, i.e., every member of the National Police must provide equal treatment regardless of rank, official, social status, economy, race, class, and religion;

The police in providing services to the community must be professional and heed their professional ethics. In the Republic of Indonesia Police Regulation Number 7 of 2006 concerning the Code of Ethics for the Police Profession, it is explained in (Article 10) that members of the National Police are obliged to avoid disgraceful acts that can damage the honor of the profession and organization and to uphold the values of honesty, justice and for the sake of service to the public. Society always: (1) Provide correct and not misleading information; (2) Be sincere and friendly in answering questions about the development of organizational services and police work procedures; (3) Must not refuse requests for help or assistance from the community because it is not their jurisdiction; (4) Do not find fault with society; (5) Do not issue words or gestures aimed at getting rewards for services provided to the community.

The above is very clearly explained regarding the police officers as protectors and public servants. Salatiga Police in terms of services, namely traffic services, issuance of Driving License (SIM), STNK Management, Police Record Certificate (SKCK), Sabhara, SPKT (Integrated Police Service Center). Before starting the activity, the police officers held a morning rally aimed at coordinating members and at the same time providing work motivation always to provide excellent or maximum service to the community. By prioritizing service, police officers always direct people who want to do management with a polite attitude, but some sit quietly while smoking cigarettes and joking with each other. Each individual has different characteristics and attitudes and the provision of services. Each individual has their way of serving the community. Some do according to the procedure, but some services do not according to the process, for example, if we give a pack of cigarettes or an envelope containing a banknote, we will be served quickly without following the prescribed procedure, 
this kind of attitude has deviated from the code of ethics. Not everyone is honest when carrying out their duties, especially police officers, which damages the image of the police in society.

Changes in work procedures are influenced by advances in mindset and the point of view that work is sole to collect material, deviating from a work culture that is by the provisions of the rules so that individuals who carry out tasks arbitrarily impose society that leads to material (money). Police services to the community do not always provide a sense of satisfaction and comfort. Sometimes tensions and conflicts occur between the police and the community. The causes are the exclusion and preference for servants and arbitrary persons in taking action against the people who commit violations. Deviant treatment when making decisions and actions that are not under the rules is the same as ignoring work culture. Police service can not be said to be good so that people are not satisfied and even feel aggrieved. Convoluted services and not applying the queue culture make people feel disadvantaged, especially the loss of time. Everyone has a particular preoccupation; therefore, time must be used as well as possible to handle all work properly. If the service is convoluted, it is the same as wasting time, a service that only takes a little time, but due to unprofessional performance, it takes a long time, which happens to services.

\subsection{Constraints Faced by the Police in Implementing Standard Operating Procedures (SOP) in SKCK services}

The police are also reforming the service to issue Good Behavior Letters, called Police Records Certificates (SKCK). In a sense, the letter refers to the presence or absence of police records owned by that person. At the Polda/Polres/Polsek level, the processing time will only need one working day, and at the Police Headquarters, the management will only take two hours. The public is asked to complete the requirements so that they can be achieved easily. The public will be able to follow all stages of the case quickly to prevent fraud.

According to Law Number 25 of 2009 concerning public services, the state must serve every citizen and resident. Public service by the government is one manifestation of the function of the state apparatus as a public servant and being a servant of the state. Still, one of the problems that often arise between the government and the community is in the field of public service itself, especially in terms of quality. Or the quality of service of government officials to the community. As a service provider for the community, the government is required to provide the best possible service.

To improve the quality of services, it must be balanced with efforts to optimize the performance of government officials and do it consistently and improve facilities and infrastructure that support the smooth running of services by their functions. The function of public services is one of the fundamental functions that the government must carry out both at the central and regional levels. Given that the primary part of the government is to serve the community, the government needs to continue to improve the quality of service. One of them is the service of making a Police Record Certificate (SKCK).

Police service can not be said to be good so that people are not satisfied and even feel aggrieved. Convoluted services and not applying the queuing culture make people feel disadvantaged, especially the loss of time. Everyone has a particular preoccupation; therefore, time must be used as well as possible to handle all work appropriately. If the service is convoluted, it is the same as wasting time, a service that only takes a little time, but due to unprofessional performance, it takes a long time, which happens to services. 
In the process of public services, it does not always run as expected. There are still obstacles to the delivery of public services, such as a shortage of human resources, as indicated by the lack of permanent workers in the service part of the service section, who must have mastered the service process. Other impeding factors, in addition to employee resources, include facilities and infrastructure, such as the lack of a filing cabinet for archive storage, which causes document storage to be disorganized, causing employees to have difficulty finding required archives and disrupting the neatness of the service room. When carrying out the service procedure, this untidiness creates inconvenience to service users.

Salatiga Police Station, whose services are in high demand in the community, must continue to deliver the finest service possible in order to improve public services and provide good service. The critical power of civil society towards the performance and image of the police is a reflection of how strong the aspirations and demands for the rights of the people are under the authority of the police. As stated in PERMENPAN-RB Number 13 of 2009, in public organizations (government organizations and their units), As part of Indonesia's broader reform of government management, enhancing the quality of public services is a must. As a result, public service delivery is a strategic point where public faith in the government is at risk. Government agencies carry out various ways to revive public trust. One example of a government agency that seeks to improve service quality and restore public confidence is the Indonesian National Police.

Police is a function of the state government that maintains and secures public order, law enforcement, protection, protection, and service to the community. In service to the community itself, the Indonesian National Police cannot be separated from the administrative service process. Judging from the function of carrying out state administration and administration of police institutions related to correspondence, "There are various kinds of providing correspondence services in the police. This is done as a form of function and authority of the police in state administration. According to the Regulation of the Head of the State Police of the Republic of Indonesia Number 23 of 2010 covering the organizational structure and working processes of the police, the administration of correspondence services is carried out by police institutions at the district/city level.

Of course, there must be items in any service that make labor more comfortable in order to get the best outcomes. The first component that encourages the establishment of good service is the excitement that workers show for one another as they strive to deliver the finest service possible to service consumers in need. The excitement of each employee is a key aspect in enabling us to give even greater service. Encourage each other to deliver services based on their unique areas of expertise in order to achieve exceptional service. We have coordination meetings or a form of review every three months discussing our community services, in addition to encouraging one another. If service staff are still unable to deliver good service after a discussion, recommendations will be made.

Meanwhile, creating awareness to serve the community honestly and with conscience is another component that fosters effective implementation. The availability of infrastructure and facilities that make it simpler for us to carry out the service process to service users, meaning the growth of consciousness to serve the community truly and with conscience, is a supportive element for us. Service personnel have an obligation to serve service consumers if they are paying attention. Another enabling aspect is the availability of facilities that assist personnel in carrying out their responsibilities to serve service consumers, such as computer aids and gadgets and an internet connection to ensure a seamless service process. 


\section{Conclusion}

Changes in work procedures are influenced by advances in mindset and the point of view that work is sole to collect material, deviating from a work culture following the rules' provisions so that individuals who carry out tasks arbitrarily impose society that leads to material (money). Police services to the community do not always provide a sense of satisfaction and comfort. Sometimes tensions and conflicts occur between the police and the community. The causes are the exclusion and preference for servants and arbitrary persons in taking action against the people who commit violations. Deviant treatment when making decisions and actions that are not following the rules is the same as ignoring work culture. Police service can not be said to be good so that people are not satisfied and even feel aggrieved.

Convoluted services and not applying the queue culture make people feel disadvantaged, especially the loss of time. Everyone has a particular preoccupation; therefore, time must be used as well as possible to handle all work properly. If the service is convoluted, it is the same as wasting time, a service that only takes a little time, but due to unprofessional performance, it takes a long time, which happens to services. To improve the quality of services, it must be balanced with efforts to optimize the performance of government officials and do it consistently and improve facilities and infrastructure that support the smooth running of services by their functions. The function of public services is one of the fundamental functions that the government must carry out both at the central and regional levels.

Given that the government's fundamental job is to serve the people, it must continue to enhance the quality of its services. One of them is the service of making a Police Record Certificate (SKCK). Police service can not be said to be good so that people are not satisfied and even feel aggrieved. Convoluted services and not applying the queuing culture make people feel disadvantaged, especially the loss of time. Everyone has a particular preoccupation; therefore, time must be used as well as possible to handle all work appropriately. If the service is convoluted, it is the same as wasting time, which only takes a little time but is due to unprofessional performance.

\section{References}

[1] E. E. Supriyanto, "Kebijakan Inovasi Teknologi Informasi (IT) Melalui Program Elektronik Goverment dalam Meningkatkan Kualitas Pelayanan Publik di Indonesia," JIP (Jurnal Ilmu Pemerintahan) Kaji. Ilmu Pemerintah. dan Polit. Drh., vol. 1, no. 1, pp. 141-161, Apr. 2016, doi: 10.24905/jip.1.1.2016.141-161.

[2] A. Farissa and M. Barthos, "Indonesian National Army Involvement in Action of Community Organizationsthreating the Ideology of the State," 2021, doi: 10.4108/eai.6-3-2021.2306455.

[3] M. Arafat and U. Ulfa, "Model Pengembangan Kebijakan Pelayanan Perizinan Berbasis Electronic Government Di Kota Palopo," J. Adm. dan Kebijak. Publik, vol. 5, no. 1, pp. 57-74, 2020, doi: 10.25077/jakp.5.1.57-74.2020.

[4] R. R. Radiansyah, "Reformasi Birokrasi Sebagai Upaya Mewujudkan Good Governance Melalui Kerangka Otonomi Daerah,” J. Inov. Ilmu Sos. dan Polit., vol. 2, no. 1, p. 80, 2020, doi: 10.33474/jisop.v2i1.6387.

[5] A. . Michael, The Best Police Report Writing Book With Samples, vol. 53, no. 9. 2008.

[6] E. E. Supriyanto, M. Rachmawati, and F. J. Nugroho, "Transformative Policies and 
Infrastructure Strengthening Towards the Police Era 4 . 0,” J. Bina Praja, vol. 13, pp. 231-243, 2021.

[7] N. A. Syaf and S. Suparno, "Police Efforts in Tackling Theft Crimes," 2021, doi: 10.4108/eai.6-3-2021.2306891. 